\title{
Social Networks and Civic Mobilizations (Portugal, 2012)
}

\author{
Isabel Babo (Ph.D) \\ University Lusófona do Porto, Portugal \\ Célia Taborda Silva (Ph.D) \\ University Lusófona do Porto, Portugal
}

Doi: 10.2478/ajis-2018-0027

\begin{abstract}
In Portugal, in 2012, the movement "To hell with troika! We want our lives!" emerged from digital social networks and with demonstration on the street on September 15. This social movement has patented new forms of public mobilization and protest motivated by citizens' dissatisfaction with the austerity measures of the Portuguese government, but it is part of the line of protest that has been taking place at the international level. Social networks were used to trigger mobilization, but the protest did not dispense with the traditional forms of expression in the public space, such as gatherings in the squares, rallies, marches and posters. Using a corpus taken from the written press, the event was analyzed using a theoretical and conceptual framework of theories of public space, social movements, and social networks. In this article we intend to reflect on the current protest movements, social networks and collective action, at a time when activism is exercised in electronic connections and in the street. Through this movement we aim to question whether we are facing new configurations of mobilization, visibility, public action and the creation of a common space, and / or if we are facing a continuity of the traditional social movement with the incorporation of new "repertoires of action".
\end{abstract}

Keywords: Portugal, social networks, civic mobilizations

\section{Introduction}

Digital technologies of communication have been used in recent public demonstrations of protest, in different parts of the globe, from the Arab world to Western capitals, from Turkey to Spain or Bulgaria, from the USA to Brazil, establishing new modalities of expression and public mobilization. Following the eruption of demonstrations in the Arab world, in 2010-11, various movements have used technological connections, while calling for participation, unleashing complaints, protests, and claims, and occupying the streets - Geração à Rasca (Portugal, 2011), Occupy Wall Street (2011; expanding from New York into other cities in the world), Movimiento 15-M or Indignados (Spain, 2011), Que se lixe a Troika! (Portugal, 2012 and 2013), demonstrations in Bulgaria (2013), Não vai ter Copa (Brazil, 2014; against the World Cup). Digital social networks have become the main medium for public mobilizations in large cities, leading to new forms of activism that escape the established powers. These new demonstrations of protest use the internet and mobile connecting devices with unlimited possibilities of exposure of images, word spread, and dissemination of messages. They may erupt online and rapidly expand into the streets or any other territory, being reported in real time, with live transmission of images, sounds, and speeches. Our aim is to consider these recent protest movements, focusing on the way activism has been exercised in the electronic media and in the streets, with a brief analysis of the Portuguese protest movement Que se lixe a Troika! Queremos as nossas vidas! (To hell with the Troika! We want our lives!). 


\section{The Role of Digital Networks in the New Forms of Activism}

The new communication technologies have introduced changes in the practices of mobilization (Granjon, 2011) and reconfigured the practices of interaction and activism. Considering the cases previously mentioned (Geração à Rasca, Occupy Wall Street, Indignados, Que se lixe a Troika, etc.) it is possible to notice that there has been a progressive change from collective mobilizations, included in a political, party-based, and ideological framework, to "individualized forms of expressive commitment" (Cardon and Granjon, 2013) on the internet, without any party or trade union structure. In fact, there is an individualization and self-organization of communication at the level of networks, with a tendency to the individualization of informational mobilizations - "mass self-communication" (Castells, 2009) or "mass-interpersonal communication" (Baym, 1998, apud Mercklé, 2011: 11), articulating what would once be irreconcilable: personal and individual communication with mass communication, as it can reach a global audience.

In net-activism (Di Felice, 2012, D. Cardon and F. Granjon, 2013), which is based on a new type of action in social digital networks (Di Felice, 2012), in accordance with the kind of reticular sociability that is created in them, there are no leaders nor structured social organizations to convene and coordinate the demonstrations. These new forms of diffusion, protest, public mobilization, and civic action that have emerged (Neveu, 1999; Cefaï, 2007; Rouet, 2013) have introduced changes in the forms of collective action and social movements, giving rise to demonstrations whose strength is more emotional than ideological, displaying expressions and often adopting a creative register of proclamations and claims, frequently marked by ethical principles of values and pluralism. This was the case of the demonstration "Que se lixe a Troika", which took place in Portugal, on $15^{\text {th }}$ September 2012. The mobilization revealed a new form of activism and public protest; it was not linked to any organization and there was plurality and heterogeneity in terms of participation ${ }^{1}$.

However, and considering the movements we are referring to, it is important to emphasize that the new modalities of communication and public exposure allowed by the electronic media coexist with collective action in urban spaces, either by unleashing or incorporating it. Cyberactivists resend actions of protest to urban spaces and mobilizations which start on the internet are rapidly transferred into the streets, with the symbolic meaning of the places and the scenic dimension created by the presence of all protesters in a common space (Tahrir Square in Cairo, the Gezi Park in Istanbul, Puerta del Sol in Madrid, etc). As Massimo Di Felice (2012) argues, user-actors, devices, technologies, networks, and databases are all involved in these mobilizations, which constitute new ways of inhabiting urban spaces. Net activists launch slogans, unleash protests and claims, start petitions, establish different logics of sociability, sharing expressions, gestures and emotions; they endow themselves with discursive, rhetorical, aesthetic, and expressive registers and repertoires; they intervene as activist-participants in public spaces.

These features are to be found in the demonstration of the $15^{\text {th }}$ September, a protest that started in social networks: citizen-users incited the mobilization in Lisbon and in other parts of the country, as well as in other European cities and in Brazil, claiming that the slogan was not to stay at home. On Facebook and Blogger, the protest that was felt throughout the country, and which spread to other parts of the world, was called "To hell with the Troika! We want our lives!"²

\footnotetext{
1 "The organizers of today's demonstration explained that the protest was not motivated by political parties or trade unions (headline). The organizers of the demonstration "To hell with the troika! We want our lives!" held today a press conference in Porto to clarify that this protest is spontaneous and has not been organized by political parties or trade unions. (...) The demonstration "To hell with the troika! We want our lives!" aims to unite the Portuguese so that they say "Stop!" to the austerity measures announced by the Prime Minister, said João Lima, (...) 'we are not politicians, but we are intelligent enough to see that these policies are incredible harmful, he added "We demand a retreat from the Prime Minister" (expresso.sapo.pt/promotores-da-manif-desvinculamse-de-partidos-e-sindicatos=f75357; Lusa |17:35 Sábado, 15 de setembro de 2012).

2 "In Lisbon, thousands of people are already on their way to the Plaza de España and in Oporto there are also thousands of people parading on Avenida dos Aliados against the austerity measures announced by the Government, in a protest that will also take place in other 40 Portuguese cities" (DN 15/09/2012).
} 


\title{
3. The Movement "To Hell with the Troika! We Want Our lives!"
}

On the $15^{\text {th }}$ September 2012, there was a major demonstration in Portugal. This movement was organized by a group of citizens as a reaction against the crisis the country was facing as well as against the measures politicians were taking to solve it.

On the $6^{\text {th }}$ April 2011, the Portuguese government asked for external help to solve the country's financial crisis. The failure to pay the public debt, to lower the public deficit, and the need to obtain funds to inject into public companies that were technically bankrupt led the country to sign a memorandum of understanding with the Troika (the International Monetary Fund, the European Central Bank and the European Commission). Since then, both the economic difficulties and political instability increased.

This context of difficulties and the widespread dissatisfaction led to the creation of the platform "To Hell with the Troika! We want our lives!". It was a spontaneous, horizontal movement, with no political affiliation, which quickly disseminated in social networks as a movement of ordinary citizens, from distinct areas and political persuasions. Its purpose was to channel popular discontent, while organizing a major national demonstration of democratic citizenship, so that the Portuguese could protest against the severe austerity measures.

In their manifesto they claimed:

\begin{abstract}
"We must do something extraordinary. We must take the streets and squares of the cities and our fields. We must join the voices, hands... We must do something against submission and resignation, against the bottleneck of ideas, against the dying of the collective will. We must call upon the voices, arms and legs of all people who know that the present and the future are decided in the streets. (...) The sacking (loan, help, rescue, names that are given to it, depending on the lie that they want to tell us) came together with the application of devastating political measures... The austerity imposed on us destroys our dignity and our life, it does not work and destroys democracy. We must overcome the fear that has been skillfully widespread and, once and for all, realize that we have almost nothing to lose and that the day will come when we will have lost everything because we have shut up and given up. (...) They divided us to oppress us. Let us join together to free ourselves!" (queselixeaTroikablogspot.pt $15^{\text {th }}$ September 2014)
\end{abstract}

Despite the fact that the 29 subscribers of the movement presented themselves on the internet as a group that was not organizational nor had any party affiliation, the original idea for the movement seems to have come from the organization "Inflexible Precarious" (IP). (vice.com/ptauthorruimarçal - August 8, 2013).

The four mentors of this movement were all activists of this organization and one of them was also a militant of a party (Portuguese Communist Party). The role of these four elements was to gather people, ordinary citizens, not embedded in organizations, who shared the same goals, in order to achieve a consistent group of anonymous protesters. This initiative was carried out outside the IP and the first meeting, which occurred in mid-June, took place at the home of one of the activists. The Prime Minister himself would give the demonstration proponents the idea that would serve as a motto to convene the protest. In July of that year (two months before the local elections), the Prime Minister used the phrase "to hell with the elections" in a speech, during a dinner of his parliamentary group (PSD) at the Assembly of the Republic. This same sentence was reused to create the slogan "To hell with the Troika! We want our lives!", which would turn against the government.

The group meetings were intensified and, in mid-August, João Camargo, a member of the IP and the leader of the party Bloco de Esquerda, joined them to coordinate the movement (vice.com/ptauthorruimarçal). The main worry was to increase the number of subscribers and to prepare the demonstration, expecting the logistical support of the IP. The date for the public mobilization was set, considering the moment when "the social divide" would be at its maximum, close to the presentation of the first package of the austerity measures. This way, and according to João Camargo, a "moment of rupture" would be created (vice.com / ptauthorruimarçal). A large demonstration took place on the $15^{\text {th }}$ September 2012, as the group had planned. On that day, about a million Portuguese were in the streets of their cities to protest. It was the biggest 
demonstration that occurred in the country after the revolution of the $25^{\text {th }}$ April $^{3}$.

In Lisbon ${ }^{4}$, more than 500 thousand people joined the movement. The concentration started at Praça José Fontana and ended at Praça de Espanha. There were thousands of people at the square, the music was echoing and was interrupted now and then by the speeches delivered by some of the participants. At five o'clock, the protesters followed the planned path, with their clenched fists in the air and bearing the national flag, or posters, in which one could read the phrases that expressed their emotions: "thieves"; "the people united will never be defeated"5 (Diário de Notícias [DN] 15/09/2012). Along the way, they passed by iconic locations such as Saldanha and Praça da República. The fact that the movement ended at Praça de Espanha was not occasional. Besides being an area with considerable dimensions, allowing to safely accommodate the many people who were there, therein lies the official residence of the Spanish ambassador, the country where protests against austerity would occur synchronously. On the $12^{\text {th }}$, in the text with the itinerary that had been published on Facebook, the group had referred to that they wanted the movement to be an "Iberian protest". In the city of Porto, Avenida dos Aliados was also full of people who shouted slogans against austerity. In other adhering cities, the scenery and action were identical.

At a press conference in Porto, on the same day of the demonstration and just before the protests, the organizers reinforced the fact that the movement was spontaneous and nonpartisan. One of the demonstration subscribers, stated that they did not want a protest with protagonists of political parties, trade unions or other organizations. The goal was to unite the Portuguese so that they would say "Stop!" to the austerity measures announced by the Prime Minister (Jornal de Notícias [JN] 15/09/2012). These people believed that the political inflexibility was "sinking" the country and that other measures should be taken. Therefore, they proposed solutions such as:

The renegotiation of the Portuguese debt, the negotiation between the Government and the oil companies for dropping the prices to stimulate the economy and ease the wallet of the population, increasing the rigor in terms of public asset management. (JN, 15/09/2012).

The indignation of about one million people was not totally ignored by the Government. The contribution to social security ${ }^{6}$, one of the most controversial measures of the executive, turned out to be reviewed.

The movement did not end with this demonstration of the $15^{\text {th }}$ September 2012. In 2013, there were two other major demonstrations: one on the $2^{\text {nd }}$ March, under the motto: "To hell with the Troika! - the people have the power" are no dead ends". The repertoire of social criticism intensified, as well as the demands for the solution of the economic and social problems.

This movement has raised many issues, namely the perception that if we are facing new ways of mobilization and acting in public, we must consider the repercussions these will have in the context of the contemporary public space.

\section{The $15^{\text {th }}$ September 2012: a Networked Social Movement?}

As it was previously mentioned, many of the demonstrations that took place in the streets of some European cities, as well as in other cities in the world, were called through social networks. The promoters of these mobilizations of protest, using digital platforms, presented themselves as common citizens, without any formal organization or party and ideological affiliation, claiming that

\footnotetext{
${ }^{3}$ The Portuguese revolution of the 25th April 1974 marked the end of the fascist regime and the establishment of a democracy in the country.

${ }^{4}$ The capital of Portugal.

${ }^{5}$ A slogan that marked the period around the 25th April revolution.

${ }^{6}$ It is a body set up by the Portuguese State that is constituted by the Providential System and the System for the Social Protection and Citizenship.

${ }^{7}$ This slogan also marked the period around the 25th April revolution.
} 
these large public demonstrations would express the social discontent caused by the economy and the policies of the various nation-states. Portugal faced this scenario, too, with the movement QSLT, in 2012. The analysis of this movement will help us understand whether we are before a new social phenomenon or a change in the "repertoire of action" of social movements.

Over time, the concept of social movement has evolved as society has transformed, but it has always involved collective action in the public space. The social movement was associated with the collective action process of a particular social group and the way this same group, through public demonstrations, acquired consciousness and power (Tilly, 1978); hence the relation of the concept to the industrial society of the West and the rise of the labour movement - it was organized, it had a program and a context. However, Eric Hobsbawm (1978a) showed that there were pre-industrial social movements, which he designated as "archaic" or "primitive" movements, because they were spontaneous, sporadic, localized and apolitical ${ }^{8}$. These forms of action were limited to the constraints of the historical moment. There were changes in the forms of collective action, but only in the nineteenth century, with the great economic and social changes that occurred during the industrialization.

Due to these permanent mutations and proliferation of collective actions in the turn of the twentieth century to the twenty-first century, Tilly considered it necessary to clarify that not every collective action corresponds to a social movement. The social movement is a kind of protest that goes beyond the mere occasional protest. Thus, in his work Social Movements: 1768 - 2004, he concluded that only a movement that displays a combination of certain elements, which result in a certain "formula", can be considered a social movement.

This formula combines three elements: 1) Campaigns, collective claims directed to target authorities; 2) Repertoires of action, which include a set of claiming performances such as demonstrations, public meetings, marches, petitions, statements to the media, etc.; 3) Demonstrations of WUNC (worthiness, unity, numbers, and commitment), that is, concerted public representation to demonstrate respectability, unity, numbers, and commitment on the part of the elements of the movement, members and/or followers of the cause in question.

Does the $15^{\text {th }}$ September movement display the elements that constitute a social movement? The "campaign" presupposes everything that precedes the action, which allows to sustain the motivations of the movement, giving it consistency. Within this context, we must consider all mobilization actions of the group responsible for the manifesto against the Troika, which circulated in social networks, as well as in traditional media, through the interviews of the movement subscribers. The protest had a very specific goal: to end the austerity that the government had imposed on the Portuguese people, by accepting the presence of a supranational entity - the Troika. All actions of this campaign eventually establish a relationship between the group of proponents, the group of demonstrators and the government, which resulted in the acceptance of the demands of the protest - the review of the single social tax.

Regarding the "repertoire", or action strategies, there were public meetings, demonstrations, and statements to the media. The movement did not end on the $15^{\text {th }}$ September; other events were held throughout the year 2013, including participations in other events organized at national and international levels, which shows that there were claiming performances within the movement "To hell with the Troika". As for the "demonstration" WUNC, the respectability of the actors was ensured by the heterogeneity of the people who participated in the movement, in terms of age, social class and ideology, showing intergenerational and motivational cohesion. In addition, there were nonpartisan subscribers with recognized public merit, as the composer António Pinho Vargas or the actress San José Lapa. There was an impressive number of protesters. One million people in the streets can only mean unity and identification with a cause. The commitment was certified in subsequent actions. On the $13^{\text {th }}$ October 2012, promoters and demonstrators of the $15^{\text {th }}$ September movement integrated the international protest Global Noise. In 2013, they promoted two major demonstrations, one on the $2^{\text {nd }}$ March and another one on the $26^{\text {th }}$ October, they attended the trade

\footnotetext{
${ }^{8}$ We also find "pre-industrial" movements in Portugal in the nineteenth century (Silva, 2013).
} 
union (CGTP) demonstration on the $4^{\text {th }}$ July, and they organized small actions, such as the protest at the residence of the Prime Minister and boycotts during official government acts, singing emblematic songs of the 1974 revolution, which shows a continuity plan and the responsibility of the activists.

It seems that the movement "To hell with the Troika" gathers all elements of Tilly's formula and also what Tarow (1998) and then Tilly (2004) named as modular character. The adoption of strategies, the innovation and the sharing elements that were seen in other movements and contexts were transposed into the Portuguese reality, with no loss in terms of national uniqueness.

Within this perspective, the protest QSLT corresponds to a social movement with a new repertoire of action, particularly the mobilization in technological social networks. A social movement understood structurally, with historical importance, only happens in the streets; the street is the scenario where collective action takes place. In digital networks, as far as net-activism is concerned, there are individual actions connected through technology. These individual actions of protest or claim, with a proposal for collective mobilization, may not leave the network. The conditions for the common action and claiming are only established when the subjects physically meet in a common space. As Zygmunt Bauman observes, "you belong to the community, but the network belongs to you" (EI País, $9^{\text {th }}$ January 2016). There is no online community, at most there is an "imagined community" or an "unprecedented dwelling condition" (Di Felice, 2013). Bauman also argues that networks do not unite people, they isolate them. Dialogue, physical proximity, and the feeling of what is happening in the streets are of major importance to deepen the sense of identity and solidarity that leads to group emotion and fosters the social movement, the claiming, and the production of political, institutional, or cultural changes. In social networks there is no ideological or even utopian hegemony; the subjects are only motivated by a feeling of discontent, disenchantment, and indignation before the economic and political conjuncture (Gohn, 2014: 13).

Massimo Di Felice (2013: 59) has a different view on the subject. According to Felice, "modern social movements" are quite distinct from "networked social movements", once the latter present these characteristics: 1 . Anonymity and absence of collective political identity; 2 . Discourse without ideology; 3 . Multiple cosmopolitical objectives; 4 . Strange action towards the struggle for power; 5. Networked non-hierarchic organizational format within a network; 6 . Elliptical action, which is not only directed to the exterior; 7 . Refusal of any kind of institutionalization; 8. Unpredictability; 9. Synchronous temporality; 10. Space of action: atopia and info-localities.

The movement QSLT, though it was created in and fostered by social networks, lacks some characteristics of the "networked social movements", suggesting the continuity of traditional social movements ("modern social movements"). There was no absolute anonymity, since it is known that it was an idea of four members of the Inflexible Precarious, according to the interviews they gave at the time (this association, which emerged as an informal movement in 2007, became institutionalized in July 2012, with statutes and social bodies). Moreover, there was no total absence of political identity, once two political parties were represented: the Portuguese Communist Party and Bloco de Esquerda, through their militants. On the other hand, the sense of struggle was at the basis of the discourse, with the occupation of streets and squares, showing that the will of the people must prevail. In fact, it was possible to notice a clear association with the revolutionary movement of the $25^{\text {th }}$ April, 1974, which led to the fall of a dictatorship with more than 40 years. The discourse inherent to the demonstration QSLT was undoubtedly ideological. The protesters were defending freedom, human rights, and democracy against the tyranny of the austerity policies of the Portuguese government and the international economic organizations. The sarcastic and bitter messages of the posters displayed against the prime minister and the members of the government were quite obvious. In addition, the active participation of the IP members reveals that the ideology of their organization existed in the movement QSLT. The objectives of the IP - "to regain confidence, the sense of usefulness and the strength of collective action to defend employment, fight for better wages and against precariousness" (manifesto of the Association IP) were always present during the demonstrations. The objective of this movement was very clear and it was more nationalistic than cosmopolitical; the aim was to end the excessive austerity the country was facing because of the Troika.

In terms of performance, the movement QSLT was also alien to the logic of the struggle for 
power, similarly to other movements initiated in social networks. The feminist, ecologist, or pacifist movements had no links to parties or unions and organized demonstrations, rallies, and parades in the public sphere, i.e., non-institutional processes of political action to obtain political rights. As Claus Offe states, the acquisition of political rights is fundamental for the emancipation from the state (1992: 166) and citizens must come into the streets to obtain the benefits of political power or to emancipate themselves from the state.

Though the institutionalization of the movement did not occur, it is worth noting that, in July 2014, militants of "Podemos" (Spanish party) came to Portugal to talk to QSLT activists and others about "new forms of organization". At the time, one of the organizers of the lberian meeting referred to the need of political organization: "it is time to realize that, in addition to demonstrations, we must assume forms of political organization because the demonstrations have been inconsequential" (Público, 17-07-2014), which was actually accomplished by activists of the Spanish movement 15M ( "Indignados"). In Portugal, one may assess whether the movement QSLT created a dynamics that was beneficial to the emergence of the movement Free/ Time to move forward, in 2015.

\section{Incorporation of the Internet into Public Mobilizations}

In digital networks the spatio-temporal coordinates are simulated and altered; the relations before space and time are transfigured by synchrony and atopy. There is a synchronic temporality (Di Felice), an instantaneity and "a kind of chronological implosion" ( $P$. Lévy, 1990) or a present continuum; there is a space in which technological mediations create an "atopic dwelling" that "involves communicative and informative ecosystems" (Di Felice, 2012: 43), which is understood as a space of flows (Castells, 1999), a-spatialized, de-territorialized, "floating", "hanging", "out of the ground" (Paquot, 2009: 106).

The movement QSLT emerged on the internet, but it was transferred into the streets. The use of digital communication was maintained, though, mixing virtual and physical spaces or virtual and real territories of circulation and communication. A new way of inhabiting urban spaces has emerged - the corporeal and temporal occupation cohabit, in a hybrid way, with the "constant present" and the "atopic dwelling" of the network. The urban space remains the place for collective action and public mobilization, even if these are generated in the virtual space and the nature of the occupation of physical spaces has changed. The presence here and now incorporates a new regime of visibility (and existence) that depends on digital media. The protestors, through their personal electronic devices, release images of themselves and others, information, comments, videos, and sounds. They are user-actors; each one can be user-actor-emitter-receiver-viewer, the individual-in-the-crowd, the individual-public, the individual-in-the-network (Paquot, 2009). Nevertheless, traditional media (press, radio, television) still play an important role, as well as their regime of communication and visibility. Actually, it is within these that the narrative of events is woven and, therefore, that the diachronic temporality, or the narrated time, is set.

Any person can start or join a petition or manifesto online, mobilize or be mobilized to participate in a demonstration, create a mobilization anywhere, send and receive messages and images. This new scenario surely leads to various theoretical challenges: does the incorporation of the Internet in the communicative processes of activism imply changes in the forms of collective action and social movements? Are we before the emergence of new forms of individual and collective expression, as well as citizenship, in urban public spaces? Are we before new regimes of visibility, exposure, and action, breaking or not with precedents, and incorporating new performances and repertoires of public action?

\section{Final Considerations}

Digital networks have allowed and fostered new ways of organizing collective actions. The movements programmed by political parties and unions have given way to new forms of social action and new modalities of protest and public mobilization, often without leaders and organization, emerging in digital social networks or using them as a support. These new movements, these new modalities of mobilization or public action, present themselves as a complex social challenge, 
questioning the institutional, political, and party structures.

The movement QSLT, emerging in and being supported by digital networks, revealed a new form of mobilization and action in the public space. However, this social action cannot be considered a totally new phenomenon, as there is a certain continuity in terms of modalities of collective action, i.e., the de-territorialization in the network was converted into movements of protest in the streets, linked to public places. We can say that the discontent with the austerity measures, the economic crisis, and the political institutions has fostered modalities of net-activism, while enhancing collective action in public places, thus allowing traditional areas of protest (squares and streets) to recover their major role as places for public expression. A comparative analysis of various social movements and public mobilizations, such as the movement QSLT, allows us to understand this ongoing transformation and the scope and repercussions of the use of digital networks in social movements, which both emerge in these networks and incorporate them.

Even in the digital age, and with the support of new communication and information technologies, public protest and collective action remain linked to the public space or to the common space of being-together. The fact that these mobilizations use digital social networks as well as traditional media and the public space as mediation interfaces, and as places of appearance and visibility, creates new challenges in terms of a conceptual analysis of these new movements and the emergence of new forms of citizenship in the urban environment linked to net-activism.

\section{References}

Babo, I. (2015). Espectadores e Públicos Activos, Lisboa: Editora Nova Vega.

Babo, I. e Silva, C.T. (2015). Public Sphere and Collective Action. the Portuguese Movement of the "15th September', Mediterranean Journal of Social Sciences. Vol.6, nº 6 S5, dezembro 2015, 425-433.

Cardon, D. (2011). La démocratie internet. Paris: Seuil.

Cardon, D. e Granjon, F. (2013). Médactivistes. Paris: Sciences Po, Les Presses.

Castells, M. (2009). Comunicación y poder, Alianza Editorial, Madrid, España.

Cefaï, D. (2007). Pourquoi se mobilise-t-on? Les théories de l'action collective. Paris: La Découverte.

Di Felice, M. (2011-2012). Redes Sociais Digitais. Revista Comunicação e Linguagens, $n^{\circ}$ 43-44. Lisboa: Relógio D'Água, 269-282.

Di Felice, M. (2012). Netativismo: novos aspectos da opinião pública em contextos digitais. Famecos: mídia, cultura e tecnologia. V.19, nº1. P. Alegre, 27-47.

Di Felice, M. (2013). Ser Redes: o formismo digital dos movimentos net-ativistas. Matrizes. Ano 7, n², jul./dez. São Paulo: USP, 49-71.

Hobsbawm, E. (1978). Rebeldes Primitivos. ( $2^{\mathrm{a}}$ ed.). Rio de Janeiro: Zahar Editores.

Gohn, M. G. (1997). Teoria dos Movimentos Sociais: paradigmas clássicos e contemporâneos. São Paulo: Loyola.

Gohn, M. G. (2014). Manifestações de Junho de 2013 no Brasil e praças dos Indignados no Mundo. Pétropolis: Vozes.

Lazega, E. (2014). Réseaux sociaux et structures relationnelles. Paris: Puf.

Levy, P. (1990). As tecnologias da inteligência. Lisboa: Instituto Piaget.

Mercklé, P. (2011). Sociologie des Réseaux sociaux, Paris: La Découverte.

Neveu, E. (1999). Médias, mouvements sociaux, espaces publics. Réseaux, 98, 17-84.

Offe, Claus (1992). Partidos políticos e nuevos movimientos sociales. Madrid: Editorial Sistema.

Paquot, T. (2009). L'espace public. Paris: La Découverte.

Rouet, G. (dir.) (2013). Mobilisations citoyennes dans l'espace public. Paris: L'Harmattan.

Silva, C. T. (2013). Popular protest in Portugal: The Douro region in first half of XIXth century. Academic Journal of Interdisciplinary Studies. Vol.2, n8, 91-98.

Tarrow, S. (1998). Power in Movement: Social Movements and Contentious Politics. Cambridge: Cambridge University Press.

Tilly, C. (2004). Social movements - 1768-2004. London: Paradigm Publishers.

Tilly, C. (1995). Contentious repertoires in Great Britain, 1758-1834. In M.Traugott, (Org.), Repertoires and cycles of collective action (pp. 15-42). Durham, NC: Duke University Press.

Tilly, C. (1981). As sociology meets history. New York: Academic Press.

Tilly, C. (1978). From Mobilization to Revolution. New York: Random House.

Tilly, C. (1977). Getting it together in Burgundy. Theory and Society,4, 479-504.

Virilio, P. (2004). Ville panique, Paris: Galilée. 


\section{Press}

Diário de Notícias [DN], 15/09/2012

www.dn.pt/.../milhares-contra-austeridade-nas-principais-cidades-do-pais http://www.dn.pt/inicio/portugal/interior.aspx?content_id=2771844).

Jornal de Negócios Online, 15/09/2012

www.jornaldenegocios.pt/.../fotogaleria_manifestaccedilatildeo_de_15_d...

Jornal de Notícias [JN], 15/09/2012

Jornal Público, 17/07/2014

\section{Blogs}

queselixeatroikablogspot.pt de 15 de Setembro de 2014

vice.com/ptauthorruimarçal - 8 de Agosto de 2013 